Provided for non-commercial research and education use. Not for reproduction, distribution or commercial use.

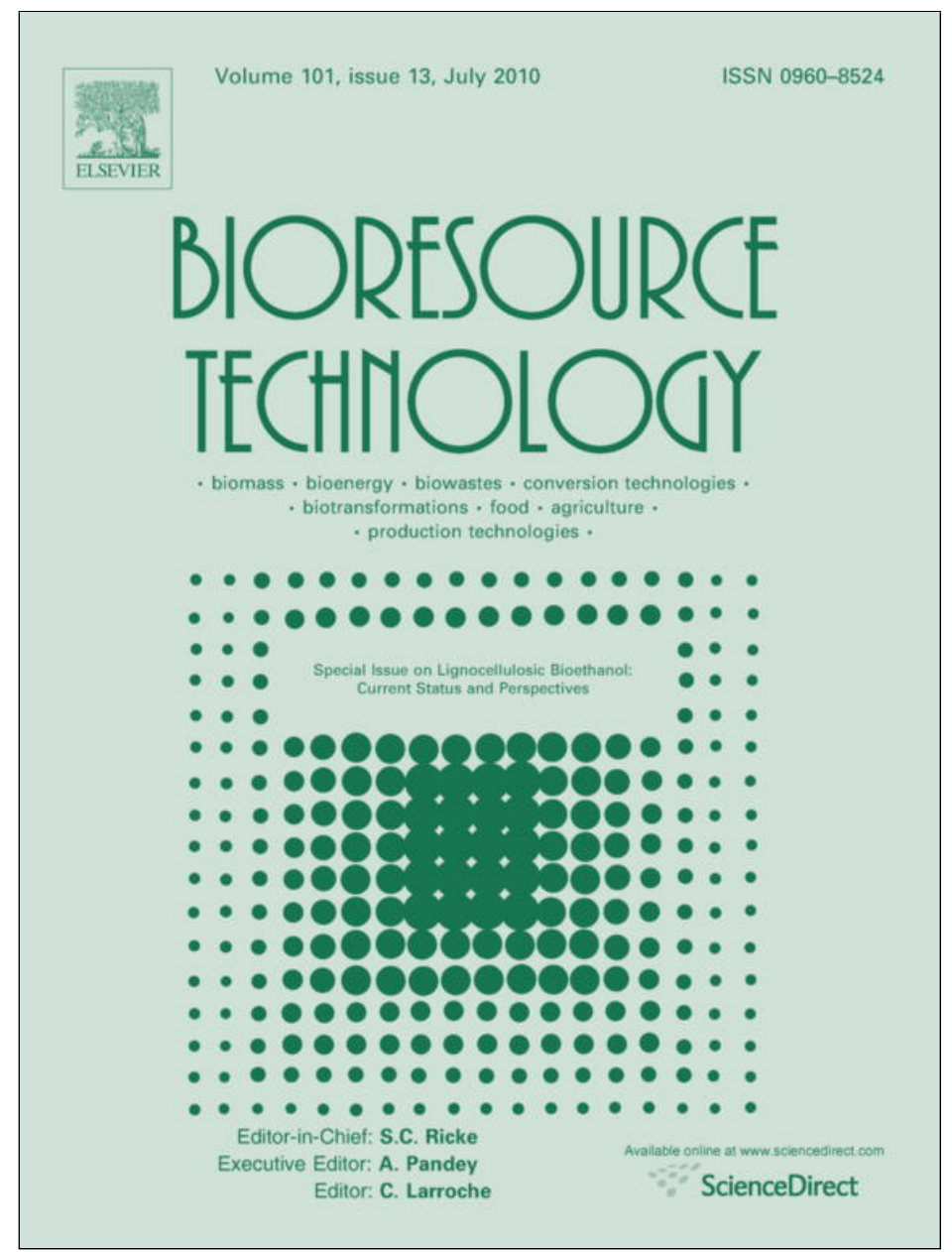

This article appeared in a journal published by Elsevier. The attached copy is furnished to the author for internal non-commercial research and education use, including for instruction at the authors institution and sharing with colleagues.

Other uses, including reproduction and distribution, or selling or licensing copies, or posting to personal, institutional or third party websites are prohibited.

In most cases authors are permitted to post their version of the article (e.g. in Word or Tex form) to their personal website or institutional repository. Authors requiring further information regarding Elsevier's archiving and manuscript policies are encouraged to visit:

http://www.elsevier.com/copyright 
Review

\title{
Production and use of lignocellulosic bioethanol in Europe: Current situation and perspectives
}

\author{
Edgard Gnansounou * \\ Swiss Federal Institute of Technology, Bioenergy and Energy Planning Research Group, EPFL ENAC INTER GR-GN, 1015 Lausanne, Switzerland
}

\section{A R T I C L E I N F O}

\section{Article history:}

Received 8 September 2009

Received in revised form 30 January 2010

Accepted 3 February 2010

Available online 2 March 2010

\section{Keywords:}

Second generation bioethanol

Sustainability

Energy substitution

Renewable energy

\begin{abstract}
A B S T R A C T
Contrary to the case of the United States where a systematic management of the RD\&D on lignocellulosic ethanol prevails, in Europe the research works remain fragmented despite the efforts made by the European Union and in few member states. In most of the European countries, sustainable lignocellulosic resources may not be widely available in the future for bioethanol production due to the possible competition between several potential usages. Thus the actual deployment of the lignocellulosic bioethanol in Europe will depend on the opportunity costs of biomass on one side and on the prices of ethanol and gasoline on the other side. While the papers on lignocellulosic ethanol often emphasize technology progress, this review paper also addresses policy measures. It is found that, especially in Europe where security of oil supply will be lower in long term, the policy instruments should explicitly reward the higher value of lignocellulosic ethanol compared to first the generation ethanol and gasoline.
\end{abstract}

(c) 2010 Elsevier Ltd. All rights reserved.

\section{Introduction}

The increasing dependency on oil imports and the growing emissions of greenhouse gases are the two main concerns which justify the introduction of public policy incentives in Europe for developing lignocellulosic ethanol. According to IEA (2008) the total world demand for oil is projected to rise by $1 \%$ per year mostly due to increasing demand in emerging markets, especially India (3.9\%/year) and China (3.5\%/year). Meanwhile, the share of OECD countries in global oil demand is expected to decrease from $57 \%$ in 2007 to $43 \%$ in 2030 . In the IEA reference scenario, the oil import dependency of OECD countries decreases from $58 \%$ in 2007 to $53 \%$ in 2030, mainly due to OECD-North America, where it drops from $44 \%$ in 2007 to $25 \%$ in 2030 thanks to Canadian non conventional sources. Conversely, oil import dependency of OECD-Europe increases from $65 \%$ in 2007 to $83 \%$ in 2030 . The situation of OECDEurope is worsened due to increase of the transport's share in the primary oil demand, from $53 \%$ in 2006 to $58 \%$ in 2030 .

The efforts laid down to improve the energy efficiency will not suffice. It will be necessary to replace progressively the fossil fuels and especially oil by renewable and more sustainable fuels. Biofuels represent one of the most prominent technical options due to possibility of blending with fossil fuels and using in the existing cars without significant adaptations. However, the first generation of commercially available biofuels suffers from their reliance on

\footnotetext{
* Tel.: +41 2169306 27; fax: +41216932863.

E-mail address: edgard.gnansounou@epfl.ch
}

food crops. Furthermore, their eventual wide scale development raises concerns about direct and indirect effects on land use.

In this respect, the sustainable production of bioethanol from lignocellulosic biomass is expected to become one of the most credible alternatives within a few years. Significant efforts in research, development and demonstration (RD\&D) are being undertaken mostly in industrialised countries with the most substantial progress made in the United States where the governmental support is more important than in any other country worldwide.

Several papers and reports dealt with various technical aspects of lignocellulosic bioethanol production in Europe. Deurwaarder and Reith, (2001) gave an overview of different processes that could convert biomass materials into ethanol and compared their economic and environmental performances. In the framework of the $R \& D$ works on lignocellulosic ethanol undertaken in the Lund University (Sweden) Galbe et al. (2007) identified the key drivers for reducing the production cost of lignocellulosic ethanol, i.e. improvement of the ethanol yield, high ethanol concentration during fermentation, improvement of pre-treatment techniques, enhancement of saccharification step as well as production of cheaper and more effective enzymes and achievement of process integration. Research works on each of these issues have been undertaken in different institutions worldwide.

Along with discussion of technical processes, this paper addresses also the policy issues and analyses the current situation and perspectives of using lignocellulosic bioethanol in Europe. Compared to the most efficient production paths such as sucrose-to-ethanol, lignocellulosic ethanol needs several technology 
breakthroughs before it could become economically competitive. Especially in Europe where cheap lignocellulosic materials are not widely available, the paper also questions about the new strategic approaches which should be conceived and implemented in order to fully address the comparative advantages of sustainable lignocellulosic ethanol.

\section{Background}

\subsection{Biofuels as policy option for energy supply diversification in Europe}

In 2007, the total primary energy supply in OECD-Europe was 76.5 EJ or 141 GJ per capita (IEA, 2009a). Oil accounted for $35 \%$ of the Total Primary Energy Supply (TPES). However, its role in the transport sector is predominant. The percentage of oil in the total final energy consumption (TFEC) of the road transport was about $97 \%$ and road transport accounted for $92 \%$ of the transport sector's TFEC. The dependency on oil imports for this sector was $65 \%$. The most significant challenge that European OECD countries will face in respect of their energy supply security will be to reduce considerably this high oil dependency. This situation is particularly alarming for Italy, Spain and Sweden, where in 2007 the contribution made by the transport sector to the final oil consumption was higher than $60 \%$ and the reliance of oil supply on import exceeded 90\% (Table 1).

Another challenge consists in the need to curb the emissions of greenhouse gases (GHG). Because of its high oil consumption, the transportation sector is the primary $\mathrm{CO}_{2}$ emitter among all other sectors in the European OECD countries. Sustainable strategies for reducing oil consumption in transport systems include the improvement of engine efficiency, substitution of oil products by natural gas, development of electric vehicles provided that electricity production derives from renewable energy.

The development of biofuels is another policy option. Biofuels have the advantage that they can be employed in the currently existing vehicles without significant adaptations. Although the spectrum of biofuels is large, biodiesel and bioethanol are the most important biofuels traded on the markets already for several decades. The world production of biofuels was estimated at $1960 \mathrm{PJ}$ in 2008: $75 \%$ bioethanol and 25\% biodiesel (IEA, 2009b). Concerning bioethanol, the share of the United States in the global production was $50 \%$ (mainly from corn), while Brazil provided $39 \%$ of the global supply (produced from sugar cane juice). The share of OECDEurope was 5\% (Table 2).

Considering that the second generation bioethanol has not reached commercial stage yet, numerous RD\&D activities aim to foster entry into the market and a rapid diffusion of this new technology. Due to its relatively fragmented political structure, the impulsion for a common European RD\&D programme on the second generation bioethanol is not as significant as in the US, where a road map and progress monitoring of the whole programme is performed on a yearly basis (DOE, 2009).

\subsection{Bioethanol versus biodiesel in Europe}

Contrary to the general situation in the world, biodiesel production in Europe is by far more important than the production of bioethanol. In 2008, 56\% of world biodiesel was produced in OECDEurope. In recent years, these so-called first generation biofuels were severely criticised due to following reasons: competition between food/feed and fuels (Eide, 2008; Fischer et al., 2009); intensification of agriculture and local environmental damages; low performances with regard to reduction of GHG emissions and substitution of fossil fuels; possible direct and indirect effects on land use (Fargione et al., 2008). Second generation biodiesel has a higher development potential in Europe compared to bioethanol because of the constantly growing importance of diesel engine vehicles in the transportation fleets. However, the potential of cost reduction is more significant for second generation bioethanol compared to biodiesel. Therefore, development of both lignocellulosic biodiesel and bioethanol is highly relevant, especially in view of the opportunities offered by biorefineries concept.

\subsection{General description of the pathways of ethanol production from lignocellulosics}

The production of bioethanol from lignocellulosic biomass includes several steps: (1) production and pre-harvest of feedstock; (2) logistics; (3) conversion to bioethanol. The oldest technology for converting lignocellulosic biomass into ethanol consists in fermenting sulphite liquors, a by-product from the pulp and paper industry. In 2008, the production of lignocellulosic bioethanol in Europe relied mostly on that technology. It is estimated that $20 \%$ of ethanol production in Sweden is based on sulphite liquors fermentation. Although it converts a derivate of lignocellulosic biomass to ethanol, this technology is not classified as second generation due to its low efficiency and its environmental burdens. The second generation bioethanol can be produced using two main production routes, i.e. thermochemical and biochemical.

The former is mainly represented by the following pathways. Bioethanol can be produced via gasification of the lignocellulosic feedstock at a high pressure and in absence of inert gases. The resulting syngas is then converted, through a catalytic synthesis, into a mixture of alcohols including ethanol as the main component. Higher alcohols such as propanol, butanol, pentanol, hexanol and others are also produced. The produced mixture of alcohols can be efficiently blended with gasoline, provided that its content in methanol is low. Meanwhile, this technology is rather old and further breakthroughs in the field of efficient catalysts are required in order to make it commercially viable. The second thermochemical pathway involves a moderate pressure (up to 3 bar) gasification

Table 1

Oil dependence and sensitivity of transport to oil in selected European countries (2007).

\begin{tabular}{|c|c|c|c|c|c|c|}
\hline Country & $\begin{array}{l}\text { Total primary oil supply } \\
\text { (EJ) }\end{array}$ & $\begin{array}{l}\text { Oil production } \\
\text { (EJ) }\end{array}$ & $\begin{array}{l}\text { Total final oil consumption } \\
\text { (EJ) }\end{array}$ & $\begin{array}{l}\text { Total final oil } \\
\text { consumption in transport } \\
\text { (EJ) }\end{array}$ & $\begin{array}{l}\text { Dependence of oil } \\
\text { supply on import } \\
(\%)\end{array}$ & $\begin{array}{l}\text { Percentage of transport } \\
\text { in final oil consumption } \\
(\%)\end{array}$ \\
\hline France & 3.43 & 0.04 & 3.25 & 1.80 & 98.7 & 55.4 \\
\hline Germany & 4.37 & 0.19 & 3.89 & 2.08 & 95.7 & 53.6 \\
\hline Italy & 3.14 & 0.26 & 2.64 & 1.67 & 91.6 & 63.1 \\
\hline Spain & 2.84 & 0.01 & 2.43 & 1.59 & 99.8 & 65.2 \\
\hline Sweden & 0.56 & 0.00 & 0.51 & 0.31 & 100.0 & 61.4 \\
\hline Dutch & 1.38 & 0.13 & 1.02 & 0.49 & 90.7 & 47.8 \\
\hline OECD-Europe & 26.54 & 9.92 & 23.55 & 13.90 & 62.6 & 59.0 \\
\hline
\end{tabular}

Source: data from IEA (2009a). 
Table 2

World production of bioethanol and biodiesel in 2008 (PJ).

\begin{tabular}{|c|c|c|c|c|c|c|}
\hline & \multicolumn{2}{|c|}{ Bioethanol } & \multicolumn{2}{|c|}{ Biodiesel } & \multicolumn{2}{|l|}{ Total } \\
\hline & $\mathrm{PJ}$ & $\%$ & $\mathrm{PJ}$ & $\%$ & $\mathrm{PJ}$ & $\%$ \\
\hline US & 740.4 & 50.4 & 88.5 & 18.0 & 829.0 & 42.3 \\
\hline Brazil & 575.3 & 39.2 & 36.6 & 7.5 & 611.9 & 31.2 \\
\hline OECD-Europe & 73.9 & 5.0 & 275.3 & 56.1 & 349.2 & 17.8 \\
\hline Others & 78.8 & 5.4 & 90.5 & 18.4 & 169.3 & 8.6 \\
\hline World & 1468.5 & 100 & 490.8 & 100 & 1959.4 & 100 \\
\hline
\end{tabular}

Source: elaborated with data from IEA (2009b)

of lignocellulosic matter in the absence of inert gases. After purification, the syngas is fermented into bioethanol at $37-39{ }^{\circ} \mathrm{C}$ using bacteria such as clostridium species (Deurwaarder and Reith, 2001; Phillips et al., 2007).

\subsection{Dominant technologies in Europe}

The currently existing pilot and demonstration plants in Europe mainly use the biochemical route which shows an important potential for further development in connection with the progress in biotechnology and the opportunities offered by biorefineries. In the biochemical pathways, the lignocellulosic feedstock is firstly pre-treated in order to make the cellulosic component more accessible to the cellulases for the subsequent enzymatic saccharification step. During the pre-treatment a significant portion of hemicelluloses is converted into monosaccharides, mostly xylose - a C5 sugar. C6 sugars - mainly glucose - are released after the enzymatic hydrolysis step and are then fermented with or without the C5 sugars depending on the design options. Several technology options are under development including separate hydrolysis and fermentation (SHF) or simultaneous saccharification and co-fermentation of $\mathrm{C} 5$ and $\mathrm{C} 6$ sugars (SSCF) with or without on-site production of the cellulases. The main challenges of the biochemical route concern the integration of the system which requires a coordinated effort in improving each step in order to achieve an overall higher efficiency and a decreased production cost of bioethanol. In that sense, a particular attention should be paid to the feedstock cost. One of the strong assumptions in developing second generation bioethanol is the possibility to process low-cost feedstocks. The idea is that second generation bioethanol could valorise agricultural or forestry "wastes". However, with time, this way of thinking is being changed. The cost of the available lignocellulosic feedstocks even in the case of agricultural residues may not remain low in long term.

\section{Current policy in the European Union}

The production of first generation bioethanol continues to rapidly increase in Europe. This situation can be explained by several factors: the market of ethanol is being well-established in several countries, such as France, where agreement between policymakers, agro-business and investors is stronger than in most other countries; the opposition to first generation biofuels is not equally strong in all European countries; the incentive given by the European Commission with its mandatory $10 \%$ market share for renewable energy in transport in 2020 in addition to the higher oil prices in 2007 and 2008 were the key drivers of the current trend of the growing production of first generation bioethanol in some European countries (see Table 3).

For various reasons, it is not sure that this trend will be sustained. Apart from the global financial crisis and economic recession that may slow down the production of biofuels in 2009 and 2010 , some structural factors are also unfavourable to the first generation biofuels in a longer term. The production cost of the first generation bioethanol depends highly on the costs of agricultural feedstocks, which, in turn, also depends on the food market worldwide. On the one hand, assuming that investments required to increase the production of the agriculture sector in developing countries will not be fully realised in the medium term due to limitations in production factors such as land, water, energy and capital, the pressure on agricultural commodities prices will not completely disappear. On the other hand, the incentives given by the European Commission and some Member States which decided on mandatory targets of biofuels consumption will mainly encourage production by big companies because of two factors. First, one has to consider the high volatility of crude oil and gasoline prices (Fig. 1) which is likely to increase the uncertainty about potential revenue and therefore become a major disincentive for new entrants into the market.

This factor of industrial concentration is reinforced by the scale economy of bioethanol production that is not favourable to small producers. These two reasons suggest that the current upward trend in the production of first generation biofuels may dissolve in the long term, maintaining the ethanol price at a high level, primarily, due to insufficient European production with regard to the forecasted demand and, secondly, due to commercial barriers to imports from low-cost producing countries such as Brazil. The way to cope with this medium-to-long term dead-end of first generation bioethanol is to promote a faster deployment of sustainable second generation bioethanol as well as biorefineries through innovation and policy support instruments.

Several policy commitments pave the way for the promotion of biofuels in the European Union (EU). The latest most significant decision is the Directive issued on 23 April 2009 on the promotion of the use of energy from renewable sources (EU, 2009a). The EU introduced a global target for renewable energy to reach $20 \%$ of final energy consumption by 2020 . Within this target, a mandatory proportion of renewable energy of $10 \%$ was required for each Member State as a percentage of energy used in road and railway transport. This new directive was adopted in a period characterised

Table 3

Market share of bioethanol in selected European Countries.

\begin{tabular}{|c|c|c|c|c|}
\hline Country & Consumption of gasoline (PJ) & Consumption of bioethanol (PJ) & Consumption of gasoline and bioethanol (PJ) & Market share of bioethanol (\%) \\
\hline France & 387.9 & 22.2 & 410.1 & 5.41 \\
\hline Germany & 886.6 & 17.2 & 903.9 & 1.91 \\
\hline Italy & 495.9 & 1.2 & 497.1 & 0.25 \\
\hline Dutch & 182.3 & 6.2 & 188.4 & 3.27 \\
\hline Spain & 276.9 & 6.2 & 283.0 & 2.18 \\
\hline Sweden & 165.4 & 9.0 & 174.4 & 5.14 \\
\hline UK & 709.4 & 1.2 & 710.6 & 0.17 \\
\hline Others & 1298.1 & 10.8 & 1308.9 & 0.82 \\
\hline OECD-Europe & 4402.5 & 73.9 & 4476.5 & 1.65 \\
\hline
\end{tabular}

Source: elaborated using data from IEA (2009a,b). 
by a high uncertainty concerning the social acceptance of biofuels. Therefore the concerns about sustainability were largely taken into account. With regard to biofuels, the main provisions of the directive were as follows: (1) the $10 \%$ mandatory target should be achieved by a balanced combination of domestic production and imports; (2) biofuels must be sustainable in order to be considered compliant with the target; (3) the Community will promote sustainability criteria for biofuels as well as the deployment of second and third-generation biofuels; (4) biofuels made from biomass originated from bio-diverse lands will not be eligible for incentives in the framework of the directive; (5) to comply with the directive, biofuels shall lead to at least 35\% saving of GHG emission starting from the date of entry into force of the directive, this value was set to $50 \%$ with effect from 1st January 2017 and from the 1st January 2018, biofuels produced by installations in which production started on or after 2017 shall save at least $60 \%$ GHG emission compared to the substituted fossil fuels; (6) for the estimation of the $10 \%$ target, the contribution made by the biofuels produced with non-food cellulosic and lignocellulosic materials shall be considered to be twice that made by other biofuels.

Another directive has been issued that enables the blend of up to $10 \% \mathrm{v} / \mathrm{v}$ bioethanol with gasoline (EU, 2009b). These blends were previously limited to $5 \% \mathrm{v} / \mathrm{v}$. Generally, all these new directives are particularly favourable to the second generation bioethanol and should foster a stable regulatory framework in the Member States for investment in RD\&D of those fuels. Apart from the non competition with food crops, the perceived advantages of second generation bioethanol are as follows: (1) higher GHG emissions reduction compared to the most of first generation production pathways; (2) possibility to use low-cost lignocellulosic feedstocks; (3) more stable ex-works production costs; (3) possibility to avoid loss of soil quality linked to monoculture; (4) lower impact on water quality and on water use; (5) more geographical diversity of production origins.

It is commonly accepted that bioethanol from lignocellulosic feedstocks could result in a higher GHG emission reduction which is estimated in the range of $70-85 \%$ (EU, 2009a) provided that there is no net carbon emission from land use. Sustainable use of agricultural residues (e.g. wheat straw) is particularly beneficial with regard to GHG emission saving. The economics of the second generation bioethanol relies on the assumption that it will be possible to use in a sustained way a low-cost feedstock (e.g. residues). With this assumption in mind, the production costs should be more stable compared to the first generation biofuels, where feedstock represents a higher proportion of the production cost, and its price is much more volatile as it is linked to agricultural commodities. The impact on soil and water of second generation bioethanol may be favourable, except the case of intensive energy crops using irrigated plantations. Finally, compared to the first generation bioethanol which is an oligopoly market with the US and Brazil being the main producing countries, lignocellulosic bioethanol relying on agricultural or forestry residues could show more geographical diversity. It is commonly expected that Europe could contribute to a much greater extent to the development of this pathway, whereas its role in the first generation bioethanol market is less supported by the public opinion in a longer term vision.

Nevertheless, some negative remarks from a few scientists and NGOs do exist even against the second generation ethanol. The most significant issues that are put forward are as follows: (1) second generation bioethanol is not the best way to valorise lignocellulosic biomass from energy perspective: gasification and cogeneration of heat and power can be considered as more energy efficient; (2) the mitigation cost of GHG emissions using second generation bioethanol is too high compared to other technological options; (3) the perspective of reducing the production cost of lignocellulosic bioethanol is uncertain as this requires that several technological breakthroughs are achieved; (4) lignocellulosic bioethanol is most sensitive to economy of scale and therefore will require a large amount of biomass, meanwhile agricultural residues with their low energy density may lead to a high cost of logistics (collection, transport and storage), this is why energy crops will be necessary with the consecutive risk of negative effects on the land use; (5) second generation bioethanol is only a way to go around the opposition against (first generation) ethanol and to give a second life to the reign of internal combustion vehicles.

Despite the innovative characteristic of second generation biofuels, their perception by general public opinion in Europe is uncertain. This is mostly due to the strong opposition raised against the first generation and the perceived correlation between the development of both first and second generations. It is indeed coherent to believe that the early commercial plants using second generation technology will be derived from well-established industry of first generation bioethanol. However, the pace of transition from the first to second generation bioethanol will strongly depend on the support of public authorities. Before the new Directive on the promotion of the use of energy from renewable sources, another directive issued in 2003 recommended a common EU target of $5.75 \%$ biofuels in energy consumption by 2010 and each member state defined its own targets.

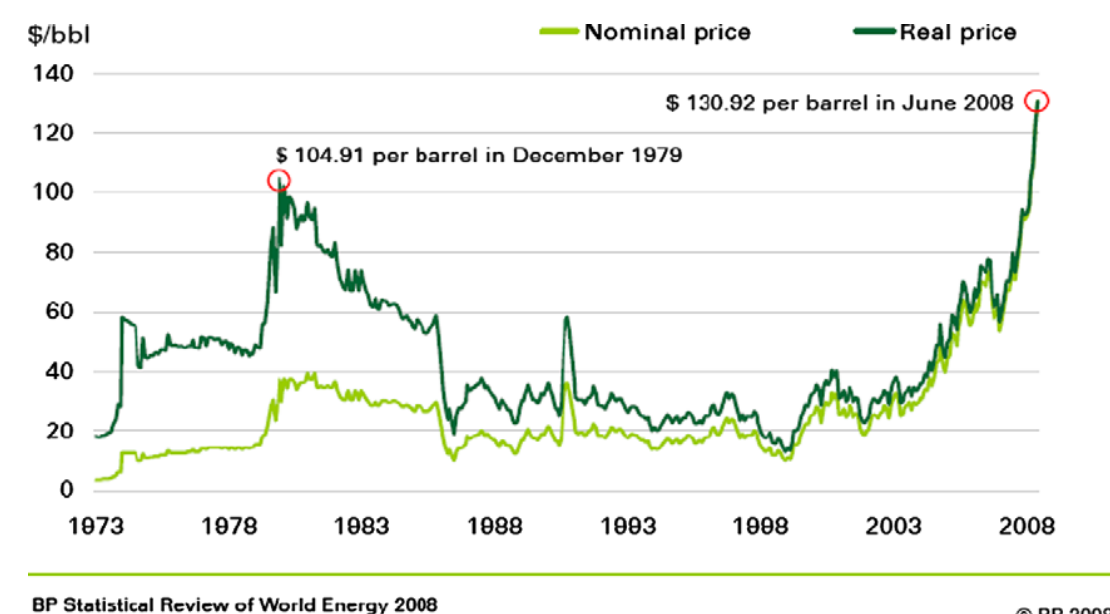

Fig. 1. Volatility of oil prices. 
Table 4

Incentives for biofuels promotion in selected EU member states.

\begin{tabular}{|c|c|c|}
\hline & Obligation: targets for biofuels mandates & Tax reduction ( $€ /$ litre biofuels) \\
\hline UK & $\begin{array}{l}\text { Percentage by volume } \\
\text { 2008: } 2.5 \% \\
\text { 2009: } 3.25 \% \\
2010: 3.5 \% \\
2011: 4 \% \\
2012: 4.5 \% \\
2013-2015 \text { onwards: } 5 \%\end{array}$ & $\begin{array}{l}0.29 € / 1 \text { biofuels } \\
\text { This fiscal incentive is in place until April } 2009\end{array}$ \\
\hline Germany & $\begin{array}{l}\text { Percentage by energy } \\
\text { 2009: } 5.25 \% \\
\text { 2010-2014: } 6.25\end{array}$ & $\begin{array}{l}\text { Until 31.07.2006: complete tax exemption on biofuels } \\
\text { Since 01.07.2006: full tax for blends of first generation biofuels with fossil fuels except E85. }\end{array}$ \\
\hline 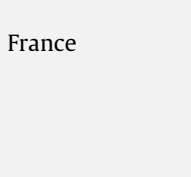 & $\begin{array}{l}\text { Percentage by energy } \\
\text { 2008: } 5.75 \% \\
\text { 2009: } 6.25 \% \\
\text { 2010: } 7 \%\end{array}$ & $\begin{array}{l}\text { Tax reduction for E85 and second generation bioethanol: } 0.65 € / 1 \\
€ / \text { litre bioethanol } \\
28: 00.3 \\
29: 00.2 \\
30: 00.2 \\
32: 00.1\end{array}$ \\
\hline The Netherlands & $\begin{array}{l}\text { Percentage by energy } \\
\text { 2008: } 2.5 \% \\
\text { 2009: } 3 \% \\
\text { 2010: } 3.5 \%\end{array}$ & Tax exemption for biofuels ends at 31 December 2006 \\
\hline
\end{tabular}

\section{Policy case studies of selected countries}

In 2008, in the light of the biofuels debate, several EU Member States have changed their targets. So, the existing policy instruments were weakened in Germany and the UK (Table 4).

\subsection{Case of the UK}

With the aim to reduce the GHG emissions in the transportation sector and to increase the security of energy supply, the government of the UK decided to adopt a Renewable Transport Fuel Obligation (RTFO) for suppliers which trade a certain amount of fuels. The RTFO entered into force in April 2008 with an obligation of 2.5\% biofuels market share target on volume basis. A carbon balance and sustainability certification as well as monthly reporting were required under the authority of the "Renewable Fuels Agency" (RFA). However, in July 2008, a review published by the chair of the RFA on the request of the government warned the public authorities to slow down the pace of this mandatory development of the use of biofuels. The reasons of that proposition were the significant potential of first generation biofuels to foster direct and indirect negative effects (land use, land pressure, food, feed, water resource). An amendment to the RTFO was then voted by which the target of $5 \% \mathrm{v} / \mathrm{v}$ mandated for 2010/2011 was postponed to 2013/2014. Until April 2009 , a tax reduction of $€ 0.29$ per litre of biofuel was consented for E85 and for other ethanol/gasoline blends (UK, 2009).

\subsection{Case of Germany}

Before 2006, biofuels were fully exempted from tax. Since 1 st August 2006, the German biofuels policy was changed. Concerning bioethanol, only E85 based on first generation bioethanol and all blends with second generation bioethanol can benefit from tax reduction of $€ 0.65$ per litre of ethanol. Since 1st January 2007 mandatory targets were adopted. They were reduced since April 2009 to $5.25 \%$ by energy content for 2009 and $6.25 \%$ by energy content for 2010-2014 (DE, 2009). In 2008, the market share of biofuels in Germany was $5.9 \%$.

\subsection{Case of France}

Contrary to the cases of the UK and Germany, the targets of biofuels market share were more ambitious than those recommended by the biofuels directive 2003/30/EC. The French government decided on $5.75 \%$ and $7 \%$ by energy content for 2008 and 2010 , respectively, and an indicative $10 \%$ target in 2015 . Tax reductions applied to bioethanol will decrease progressively until 2011 (FR, 2009). R\&D projects on second generation bioethanol are funded by two institutions: the Agency for the Environmental and Energy Management (ADEME) and the French National Research Agency (ANR).

\subsection{Case of the Netherlands}

As in the cases of the UK and Germany, the mandatory targets of biofuels set up in the Netherlands in 2007 have been reduced in 2008 in order to take into account the concerns about competition with food and feed. The target for 2010 is lower than the recommendation of the EU directive on biofuels of 2003. No tax exemption is given to bioethanol blends (NL, 2009).

\section{Pilot and demonstration plants}

Besides the policy instruments to promote bioenergy which will also profit to second generation bioethanol, there are direct investments in R\&D, pilot and demonstration plants. Although lower in

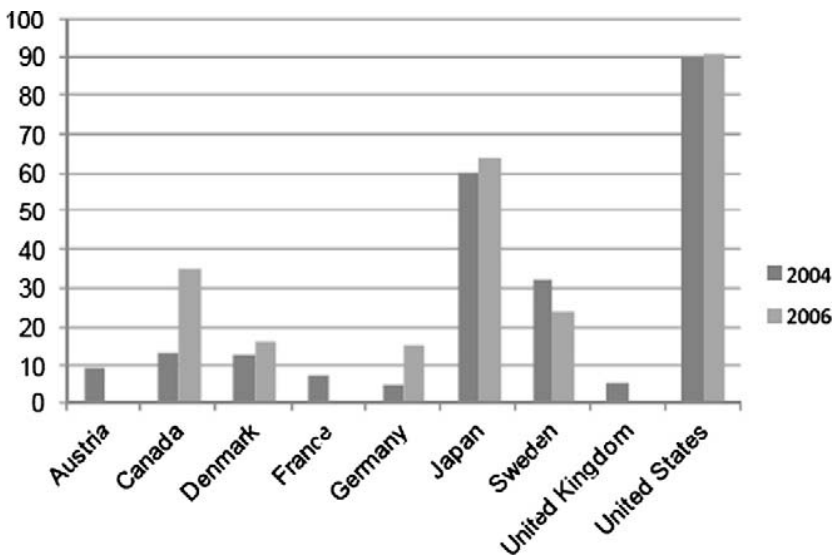

Fig. 2. Public R\&D expenditures for bioenergy in 2004 and 2006 Extract from OECD (2008). 
comparison to the U.S., the public support from common EU funds as well as from individual countries' R\&D budgets is granted for the development of bioenergy (Fig. 2).

Several times the EU has issued calls for proposals for second generation biofuels R\&D projects within its seventh Framework Programme (FP7) and 139 millions Euros were allocated to biofuels and biorefinery R\&D for the calls of 2007 and 2008 (OECD, 2008). Currently, several R\&D projects as well as pilot plants and demonstration projects on second generation bioethanol are being implemented in Europe (Table 5).

The three pilot plants in operation before 2009 were those of Frederica in Denmark, Örnsköldswik in Sweden and Copenhagen in Denmark. The ethanol production capacity varied from $1 \mathrm{t} /$ year to $1100 \mathrm{t} /$ year. The demonstration plants were at different levels of maturity. While few of them were in advanced stage (Abengoa, Inbicon, BioGasol), others were still in the design phase.

\subsection{Case of SEKAB}

Located in Örnsköldsvik - Northern part of Sweden - the pilot plant of SEKAB started production in 2005. The plant has the capacity to produce 300-400 litres of bioethanol per day from 2 tons of dry biomass. The feedstock is forestry residues (wood chips from pine trees). Other lignocellulosic feedstocks such as sugarcane bagasse, wheat and corn stover as well as energy grass can be also used. The plant can operate with two options: (1) twostage dilute acid hydrolysis in either co-current or counter-current mode; (2) dilute acid pre-treatment step followed by simultaneous enzymatic saccharification and fermentation (Galbe et al., 2005). In the two-stage dilute acid hydrolysis, he first stage, i.e. prehydrolysis, is operated under less severe conditions e.g. $0.7 \%$ $(\mathrm{w} / \mathrm{w}) \mathrm{H}_{2} \mathrm{SO}_{4}$ at $190{ }^{\circ} \mathrm{C}$ and a 3-min residence time, which maximize the hydrolysis of the hemicellulose. At the second stage, the conditions are optimised, e.g. $0.4 \%(\mathrm{w} / \mathrm{w}) \mathrm{H}_{2} \mathrm{SO}_{4}$ at $215^{\circ} \mathrm{C}$ and a 3-min residence time, for efficiently achieving the saccharification of the cellulose fraction. The actual process parameters depend on the lignocellulosic materials e.g. softwood, hardwood or agricultural residues. The reported disadvantages of the dilute acid process include the relatively low ethanol yield, the potential corrosion due to the use of sulphuric acid at high temperature and the large amounts of by-products of the acid neutralization such as gypsum $\left(\mathrm{CaSO}_{4}\right)$. A detailed description of the second process can be found in Wooley et al. (1999). The roadmap of the ethanol production includes three steps: a demonstration plant in 2011, an industrial demonstration in 2014 and a commercial plant in 2016 (SEKAB).

\subsection{Case of Abengoa Bioenergy: BCyL biomass plant}

The demonstration plant of Abengoa Bioenergy is located in Babilafuente in Salamanca (Spain). The plant has the capacity to process 70 tons of agricultural residues per day and to produce five million litres per year. The feedstock is basically wheat straw and the conversion technology is the separate enzymatic hydrolysis and fermentation - SHF. The start-up is planned for 2009. The plant is next to a 195 Million litres/year cereal ethanol plant and integration of both first and second generation is envisaged (ABENGOA).

\subsection{Case of BioGasol}

Since August 2006, the company BioGasol operates the Maxifuel pilot plant at the Technical University of Denmark. The capacity of the plant is 10t ethanol per year. The company is developing one of the first Danish demonstration- ethanol plants of second generation. With a capacity of 5.2 million litres ethanol per year the BornBiofuel plant is expected to be fully operational in 2010 (BIOGASOL). The process technology is a four-step SSF: (1) the pre-treatment consists in a proprietary process based on a combination of steam-explosion and wet oxidation (Ahring et al., 1999) using both addition of oxygen and a pressure release at a temperature in the range of $179-200{ }^{\circ} \mathrm{C}$; (2) a simultaneous saccharification and fermentation of glucose is performed; (3) xylose is fermented using a proprietary thermophilic anaerobic bacterium; (4) the process water is converted in biogas and the water is reused.

\subsection{Case of Inbicon and DONG Energy}

Inbicon, a subsidiary of the Danish DONG Energy, is developing a second generation ethanol demonstration plant which is supposed to be in service from December 2009. The Kalundborg plant will use wheat straw feedstock to produce 5.4 million litres of ethanol per year. The process will consist in a SSF with a hydrothermal pre-treatment. The heat will be provided by a cogeneration plant that will use solid fuel based on the valorisation of lignin according to the "Integrated Biomass Utilization System IBUS" concept. The surplus of electricity will be sold to the electrical network Larsen et al., 2008).

\section{Perspectives}

A global "Vision for 2030 and Beyond" was elaborated by the European Commission according to which the contribution made

Table 5

Second generation bioethanol, pilot, demonstration and projected commercial plants in Europe.

\begin{tabular}{|c|c|c|c|c|}
\hline Operator & Location & Ethanol capacity & Scale & Status \\
\hline Abengoa Bioenergy & Salamanca, Spain & $4000 \mathrm{t} / \mathrm{yr}$ & Demo & Under construction, start-up 2009 \\
\hline BioGasol & Bornholm, Denmark & $4000 \mathrm{t} / \mathrm{yr}$ & Demo & Planned start-up 2009 \\
\hline DTU, BioGasol & Copenhagen, Denmark & $10 \mathrm{t} / \mathrm{yr}$ & Pilot & Operational, start-up 2006 \\
\hline SEKAB & $\begin{array}{l}\text { Örnsköldsvik, Sweden } \\
\text { Örnsköldsvik, Sweden } \\
\text { Örnsköldsvik, Sweden } \\
\text { Örnsköldsvik, Sweden }\end{array}$ & $\begin{array}{l}100 \mathrm{t} / \mathrm{yr} \\
4500 \mathrm{t} / \mathrm{yr} \\
50,000 \mathrm{t} / \mathrm{yr} \\
120,000 \mathrm{t} / \mathrm{yr}\end{array}$ & $\begin{array}{l}\text { Pilot } \\
\text { Demo } \\
\text { Demo } \\
\text { Comm. }\end{array}$ & $\begin{array}{l}\text { Operational, start-up } 2004 \\
\text { Planned, start-up } 2011 \\
\text { Planned, start-up } 2014 \\
\text { Planned, start-up } 2016\end{array}$ \\
\hline Inbicon, DONG Energy & $\begin{array}{l}\text { Fredericia, Denmark } \\
\text { Fredericia, Denmark } \\
\text { Kalundborg, Denmark }\end{array}$ & $\begin{array}{l}110 \mathrm{t} / \mathrm{yr} \\
1100 \mathrm{t} / \mathrm{yr} \\
4000 \mathrm{t} / \mathrm{yr}\end{array}$ & $\begin{array}{l}\text { Pilot } \\
\text { Pilot } \\
\text { Demo }\end{array}$ & $\begin{array}{l}\text { Operational, start-up } 2003 \\
\text { Operational, start-up } 2004 \\
\text { Under construction, start-up } 2009\end{array}$ \\
\hline Procethol 2G, Futurol & $\begin{array}{l}\text { Pomacle, France } \\
\text { Pomacle, France }\end{array}$ & $\begin{array}{l}140 \mathrm{t} / \mathrm{yr} \\
2840 \mathrm{t} / \mathrm{yr}\end{array}$ & $\begin{array}{l}\text { Pilot } \\
\text { Demo }\end{array}$ & $\begin{array}{l}\text { Under construction, start-up } 2010 \\
\text { Planned }\end{array}$ \\
\hline Süd-Chemie & Münich, Germany & $2 \mathrm{t} / \mathrm{yr}$ & Pilot & Operational, start-up 2009 \\
\hline
\end{tabular}


by the biofuels to the transportation fuels consumption in Europe can be as much as $25 \%$ by 2030 (EC, 2006). Compared to the $10 \%$ mandatory target for 2020 decided in the new directive on renewable energy, the 2006 vision seems ambitious and should be considered as an optimistic assumption. A more realistic assumption could be a target around $15 \%$.

\subsection{Scenarios of the European demand for ethanol}

The proposed scenarios of the bioethanol demand in Europe by 2030 are based on the following factors: the final energy demand of the transportation sector; the contribution made by gasoline compared to diesel and kerosene; the targeted share of bioethanol in the market (gasoline + bioethanol). Two scenarios are made for EU-27, Switzerland and Norway according to which the demand for second generation bioethanol varies in the range of 0.74-2.41 EJ by 2030 (Table 6).

\subsection{Scenarios of supply of second generation ethanol}

Agricultural residues, forest wood, by-products of the wood industry, and energy crops are the main potential sources of feedstock for the production of second generation bioethanol. The biomass resource potentials in Europe have been analysed by several authors. Ericsson and Nilsson (2006) used a resource-focused approach to estimate the potential biomass supply in the EU-25. Five scenarios were proposed based on several assumptions concerning the residues harvest, energy crop yields and surplus of agricultural land. The potential supply of biomass for energy purposes was estimated at $17.2 \mathrm{EJ}$ per year. Taking into account the energy supply in the EU-15 in 2001 (62.6 EJ), they concluded that there was no important resource limitation for EU to meet its biomass energy target.

In the framework of the refuel project under the EU "Intelligent Energy" Research Programme, a systematic assessment of the biomass potential for biofuels in Europe was undertaken. Based on a Geographic Information System (GIS) modelling and national data for EU-27, Switzerland, Norway and Ukraine, land productivity (Fischer et al., 2010a) and land use scenarios (Fischer et al., 2010b) were elaborated resulting in 42.7 million ha of land available for biofuel feedstock production in EU-27, Norway and Switzerland in 2030. This production concerned energy crops such as woody species (e.g. poplar, willow and eucalyptus) and herbaceous crops (e.g. miscanthus, switchgrass and canary reed). Furthermore, the potential of agricultural residues (e.g. straw, stalk, cob, husks) were estimated at 166 million tons of dry matter.

Based on these figures and assuming that one third of the feedstock is converted into second generation bioethanol with an average energy efficiency of $35 \%$, it results that $945 \mathrm{PJ}$ of second generation ethanol could be produced in the EU-27, Norway and Switzerland by 2030 (643 PJ from energy crops; 302 PJ from residues). In terms of volume, that represents $45 \times 10^{9}$ litres of second generation ethanol in 2030 .

Table 6

Scenarios of second generation bioethanol demand.

\begin{tabular}{lll}
\hline & $\begin{array}{l}\text { "Low" } \\
\text { scenario }\end{array}$ & $\begin{array}{l}\text { "High" } \\
\text { scenario }\end{array}$ \\
\hline Final energy demand of transportation (EJ) & 20.00 & 25.00 \\
Share of gasoline (\%) & 34.00 & 28.00 \\
Target for ethanol (\%) & 15.00 & 25.00 \\
Share of second generation (\%) & 75.00 & 85.00 \\
Demand of gasoline (EJ) & 5.60 & 8.5 .00 \\
Demand of bioethanol (EJ) & 0.99 & 2.83 \\
Demand of second generation bioethanol (EJ) & 0.74 & 2.41 \\
$10^{9}$ litres & 34.96 & 113.60 \\
\hline
\end{tabular}

The comparison of this figure with the estimated demand shows that in "Low" scenario the demand can be technically met. This is not the case for "High" scenario of demand. In the latter case, $60 \%$ of the needed second generation ethanol will be imported.

There are several uncertainties about these figures. The potential of biomass supply for second generation bioethanol is influenced by the delivery cost which depends mainly on two components: the opportunity cost for the biomass producers to sell on other markets; and the logistic costs. Indeed, there are multimarket competitions including the competition among bioethanol producers, between them and other energy products, and with non-energy products which use biomass resources. The land use scenarios are also uncertain. Finally, the energy efficiency of 35\% for the conversion of lignocellulosic biomass to ethanol is rather conservative. However, these figures give an idea about the amount of second generation biofuels that could be technically possible with the potential biomass resources and can serve to policymakers to draw a roadmap for European RD\&D in that field.

\section{3. $R E D$ challenges}

The "European Biofuels Technology Platform" - an organization set up by the European Commission that mostly gathers industry stakeholders - proposed a "Strategic Research Agenda \& Strategy Deployment" (EBTP, 2008). However, these documents do not provide a detailed view as the US programme does (DOE, 2009). Few issues are discussed here below with regards to the perspectives of second generation production in Europe.

\subsection{Improving the quality and cost of the biomass resources}

The challenge of the RD\&D in biomass production is mainly twofold: improve the quality of the feedstock with regard to the specifications required by the bioethanol plant and economically improve the yield of the feedstock production chain in order to reduce the cost. As an example, the objective set up by the US programme for grower and stumpage payment was US\$15 per dry US ton in 2012 and US\$ 26.20 per dry US ton in 2017 (DOE, 2009). These objectives will vary from one region to the other.

\subsection{Logistics}

Logistics comprises harvest, storage, pre-processing, handling and transportation to the bioethanol plant gate. Another part of the logistics is the management of the storage at the ethanol plant. From a theoretical point of view, the issue of biomass logistics has been extensively studied especially in the framework of bioenergy facility location. In most cases, the contribution made by the biomass delivery cost to the total bioenergy production cost is high. Thus, an optimised location of the plant is a key factor to make the production competitive. The up-to-date approach consists in developing a GIS-based model for evaluating the feedstock supply curves (e.g. Grahama et al., 2000; Chalmers et al., 2003; Panichelli and Gnansounou, 2008). In the case of second generation bioethanol, although the contribution made by the feedstock cost is less important compared to the first generation plants, a suitable design of the logistics is one of the key factors for making the feedstock cost stable during the lifetime of the ethanol plant.

Based on the experience of the US programme (DOE, 2009), the goal of a RD\&D programme on feedstock logistics could be to improve the efficiency while reducing the cost of the logistics chain. As an idea, for the case of herbaceous plants, the logistics cost could be reduced from a targeted cost of $€ 48$ per dry ton for 2009 to $€ 30$ per dry ton in 2020 . This kind of goal should be defined in different agro-forestry zones as local conditions significantly influence the costs. The typical RD\&D tasks are as follows: (1) to in- 
crease the availability of feedstock by improving the harvesting and collection systems; (2) to reduce significantly the negative impacts of feedstock storage such as losses of dry matter and soluble sugars, changes in biomass composition; (3) to design and optimise pre-processing, such as bulk compaction, taking into account the quality required for each biomass type, as well as equipment capacity; (4) to optimise feedstock properties with respect to handling and transportation operations; (5) to integrate the whole feedstock system (biomass production and logistics) in order to optimise the efficiency and the costs.

\subsection{Conversion process}

Both thermochemical and biochemical conversion routes of lignocellulosic biomass to ethanol are being studied in Europe. The interest to develop both is the perspective of long term implementation of double-platform which integrates sugar and syngas biorefinery concepts. The goal assigned by the DOE in his programme to the biochemical route is to achieve a processing cost of US\$ 0.92 per gallon ( $€ 0.18$ per litre) by 2012 and US $\$ 0.6$ per gallon ( $€ 0.12$ per litre) for a mature facility converting corn stover. The baseline (state of the technology) estimated in 2005 was US\$ 1.79 per gallon ( $€ 0.35$ per litre).

For achieving this goal, the RD\&D programme on biochemical conversion has to deal with several challenges such as: (1) to increase the efficiency and to reduce the cost of the pre-treatment step in order to significantly improve the performance of the enzymatic hydrolysis and fermentation; (2) to cope with the variability of the feedstock characteristics; (3) to improve the understanding of the biomass recalcitrance to pre-treatment; (4) to further decrease the cost of cellulose saccharification; (5) to find the way for reducing enzyme loading without loss of performance; (6) to develop enzymes with improved thermo-stability and less susceptibility to sugars inhibition; (7) to find optimal yeasts for an efficient co-fermentation of $\mathrm{C} 5$ and $\mathrm{C} 6$ sugars; (8) to perform a process design integration in order to find the best way to achieve the overall goal when scaling-up from demonstration stage to a mature commercial facility.

\subsection{Techno-economic and environmental assessment}

While the technological development of second generation bioethanol is the most discussed issue, the economic and environmental performances of the designed pathways will be the key factors that would determine the final outcome of the multi-years efforts undertaken in a worldwide scale.

Evaluating the economic performance of bioethanol facility based on a technology which is currently at the R\&D stage is not straightforward. However, this activity is important for monitoring the numerous research tasks involved in a large R\&D programme. The techno-economic analysis used at the National Renewable Energy Laboratory (NREL) is well presented by Aden and Foust (2009) in the case of conversion of corn stover to ethanol using a dilute sulphuric acid and enzymatic hydrolysis process. For a given period, the net present value of all the cost and revenues is evaluated with a given discount rate. The value of the ethanol price that results in a zero net present value is termed "Minimum Ethanol Selling Price (MESP)".

Another approach consists in estimating the production cost of a given year by annualising all fixed costs (Hamelininck et al., 2005). Galbe et al. (2007) reviewed the different studies on the process economics of ethanol production from lignocellulosic materials published during the last decade and found that the variation of the production cost could be in the range of US\$ 0.13-0.81 per litre of ethanol. They explain these variations by the assumptions underlying the techno-economic calculations such as the cost of feedstock that can vary between US\$ 30 and 90 per metric ton and the plant capacity which influences the capital cost.

Slade et al. (2009) evaluated the commercial performance of cellulosic ethanol in Europe based on a market oriented approach for those components that are already traded on the market such as biomass. They found that in the European context of Europe the best performing path is the ethanol produced from softwood and used as low percentage blend with gasoline.

Generally, some considerations should be highlighted concerning the techno-economic evaluation of second generation bioethanol. The uncertainty related to the economic performance is high due to several factors: (1) variety of possible designs; (2) the lack of knowledge concerning how the feedstock market will behave in the long term when the feedstock demand significantly increases; (3) the lack of knowledge concerning the market price of ethanol and especially the existence or not of correlation with the price of gasoline when the share of bioethanol in road transport fuel is significant; and finally (4) the willingness of investors to be involved in the production of second generation bioethanol.

Environmental performance of second generation bioethanol concerns the global issues such as fossil oil depletion and global warming as well as local environmental impacts (impact on soil, water, air, direct land use and biodiversity). Several works have been undertaken concerning the life-cycle analysis (LCA) of bioethanol. However, LCA of second generation bioethanol has been less studied. The energy ratio in most studies is found to be higher than 1 (one), meaning that second generation bioethanol provides more renewable energy in the form of ethanol than the fossil energy used for producing, transporting and processing the feedstock. Gnansounou and Dauriat (2005) and Davis et al. (2008) provide reviews on this indicator, showing however large variations in the results found in the literature. Other references are Uihlein and Schebec (2009), Luo et al. (2009), Schmer et al. (2008), von Blottnitz and Curran (2007), Adler et al. (2007), Kim and Dale (2005), Spatari et al. (2005).

These differences in the results from one study to the other are due to the assumptions made on the limits of the system, the allocation method, how the co-products are valorised, the way by which the conversion system is fuelled and finally the composition of the feedstock. One of the advantages of lignocellulosic feedstock is the possibility to use the lignin component for fuelling the conversion process. This option may significantly improve the energy balance. The balance of GHG emissions is also largely positive compared to the most part of the first generation bioethanol, provided that land use impacts do not cause a net positive GHG emission.

The local environmental impacts vary from case to case. Generally, when agricultural residues are used, these impacts are reduced if the appropriate precautions are taken e.g. in leaving the required amount of organic materials for the regeneration of the soil. Concerning the energy crops, the choice is possible between two options such as: on the one hand, intensive energy crops culture with limited land use and the increased use of fertilisers; and on the other hand, extensive one that would increase the impacts on land use but would decrease the soil degradation and water pollution. Finally, the use of forest resources is sensitive to the biodiversity issues that must be treated with strict precautions.

\section{Conclusion}

While most of the papers on lignocellulosic ethanol prioritize technical aspects of conversion process, this review paper embraces other considerations that would impact the development of the second generation bioethanol. The analysis of the European case suggests that in the future, the economic potential of lignocellulosic ethanol may be constrained by the biomass opportunity 
costs as well as by the market price of ethanol. The deployment of the lignocellulosic ethanol production in Europe will be mainly fostered by those of the public policy instruments which will fully consider the comparative advantages of sustainable ethanol.

\section{References}

Abengoa. BCyL Biomass Plant. <http://www.abengoabioenergy.com/> (accessed 30.08.09)

Aden, A., Foust, T., 2009. Technoeconomic analysis of the dilute sulphuric acid and enzymatic hydrolysis process for the conversion of corn stover to ethanol. Cellulose 16, 535-545.

Adler, P.R. et al., 2007. Life-cycle assessment of net greenhouse-gas flux for bioenergy cropping systems. Ecol. Appl. 17, 675-691.

Ahring, B.K. et al., 1999. Production of ethanol from wet oxidised wheat straw by Thermoanaerobacter mathranii. Bioresour. Technol. 68, 3-9.

Chalmers, S. et al. 2003. A GIS-based Tool for Estimating Supply Curves for Fores Thinning and Residues to Biomass Facilities in California. Department of Biological and Agricultural engineering, University of California, Davis, $33 \mathrm{pp}$.

DE, 2009. Sixth National Report on the Implementation of Directive 2003/30/EC of 8 May 2003 on the Promotion of the Use of Biofuels or Other Renewable Fuels fo Transport. <http://ec.europa.eu/energy/renewables/biofuels/ms_reports_dir 2003_30_en.htm>. (accessed 30.08.09).

Deurwaarder, E.P., Reith, J.H., 2001. Bioethanol in Europe. Overview and Comparison of Production Processes. SenterNovem. <www.senternovem.nl/gave>.

DOE, 2009. Biomass Multi-year program Plan. Office of the Biomass Program. US Department of Energy. May 2009.

Davis, S.C., Anderson-Teixeira, K.J., DeLucia, E.H., 2008. Life-cycle analysis and the ecology of biofuels. Cell press. Trends Plant Sci. 14 (3), 140-146.

EBTP, 2008. Strategic Research Agenda and Strategy Deployment Document. European Biofuels Technology Platform.

EC, 2006. Biofuels in the Europe Union. A Vision for 2030 and Beyond. EC, Directorate-General for Research, Sustainable Energy Systems.

Eide, A., 2008. The Right to Food and the Impact of Liquid Biofuels (Agrofuels). Food and Agriculture organization of the United Nation, Rome.

Ericsson, K., Nilsson, L.J., 2006. Assessment of the potential biomass supply in Europe using a resource-focused approach. Biomass Bioenergy 30, 1-15.

EU, 2009a. Directive on the promotion of the use of energy from renewable sources. Official J. Eur. Union. 5 June.

EU, 2009b. Directive as regards the specification of petrol, diesel, and gas-oil Official J. Eur. Union. 5 June.

Fargione, J. et al., 2008. Land Clearing and the Biofuel Carbon Debt. Sciencexpress.

Fischer, Gu et al., 2010a. Biofuel production potentials in Europe: sustainable use of cultivated land and pastures. Part I: land productivity potentials. Biomass Bioenergy 34 (2), 159-172.

Fischer, Gü et al., 2010b. Biofuel production potentials in Europe: sustainable use of cultivated land and pastures. Part II: land use scenarios. Biomass Bioenergy 34 (2), 173-187.

Fischer, Gü. et al., 2009. Biofuels and Food Security: Implications of an Accelerated Biofuels Production. IIASA, Vienna.

FR, 2009. Report Assessing Actions Taken to Promote Biofuels in France in 2008 <http://ec.europa.eu/energy/renewables/biofuels/ms_reports_dir_2003_30_en. htm> (accessed 30.08.09).
Galbe, M., Lidén, G., Zacchi, G., 2005. Production of ethanol from biomass - research in Sweden. J. Sci. Ind. Res. 64, 905-919.

Galbe, M., Sassner, P., Zacchi, G., 2007. Process engineering economics of bioethanol production. Adv. Biochem. Eng./Biotechnol. 108, 3003-3327.

Gnansounou, E., Dauriat, A., 2005. Energy balance of bioethanol: a synthesis. In Proc. of 14th European Biomass Conference and Exhibition, Paris, France.

Grahama, R.I., English, B.C., Noon, C.E., 2000. A geographic information systembased modelling system for evaluating the cost of delivered energy crop feedstock. Biomass Bioenergy 18, 309-329.

Hamelininck, C.N. et al., 2005. Ethanol from lignocellulosic biomass: technoeconomic performance in short-, middle-and long term. Biomass Bioenergy 28, 384-410.

IEA, 2008. World Energy Outlook 2008. OECD/IEA.

IEA, 2009a. Energy Balance of OECD Countries. 2009 Edition. OECD/IEA.

IEA, 2009b. Medium-Term Oil market Report. OECD/IEA.

Kim, S., Dale, B.E., 2005. Life cycle assessment of various cropping systems utilized for producing biofuels: bioethanol and biodiesel. Biomass Bioenergy 29, 426439.

Larsen, J. et al., 2008. The IBUS process - lignocellulosic bioethanol close to a commercial reality. Chem. Eng. Technol. 31 (5), 765-772.

Luo, L. et al., 2009. Allocation issues in LCA methodology: a case study of corn stover-based fuel ethanol. Int. J. Life Cycle Assess. 14, 529-539.

NL, 2009. Report for 2008 Under Article 4(1) of Directive 2003/30/E on the Promotion of the Use of Biofuels or Other Renewable Fuels Transports. <http:// ec.europa.eu/energy/renewables/biofuels/ms_reports_dir_2003_30_en.htm> (accessed 30.08.09).

OECD, 2008. Biofuel Support Policies, an Economic Assessment. OECD, Paris.

Panichelli, L., Gnansounou, E., 2008. 2008. GIS-based approach for defining bioenergy facilities location: a case study in the Northern Spain based on marginal delivery costs and resources competition between facilities. Biomass Bioenergy 2000 18, 309-329.

Phillips, S. et al., 2007. Thermochemical Ethanol via Indrect Gasification and Mixed Alcohol Synthesis of Lignocellulosic Biomass. Technical Report, NREL/TP-51041168, April.

SEKAB. Ethanol Pilot plant - introduction. <http://www.sekab.com>.

Schmer, M.R. et al., 2008. Net energy of cellulosic ethanol from switchgrass. Proc. Natl. Acad. Sci. USA 105, 464-469.

Slade, R. et al., 2009. The commercial performance of cellulosic ethanol supplychains in Europe. Biotechnol. Biofuels 2, 3.

Spatari, S. et al., 2005. Life cycle assessment of switchgrass-and corn stover-derived fuelled automobile. Environ. Sci. Technol. 39, 9750-9758.

Uihlein, A., Schebec, L., 2009. Environmental impacts of a lignocellulose feedstock biorefinery system: an assessment. Biomass Bioenergy 33, 793-802.

UK, 2009. UK Report to the European Commission under Article 4 of the Biofuels Directive (2003/30/EC). <http://ec.europa.eu/energy/renewables/biofuels/ ms_reports_dir_2003_30_en.htm> (accessed 30.08.09).

Von Blottnitz, H., Curran, A.M., 2007. A review of assessment conducted on bioethanol as a transportation fuel from a net energy, greenhouse gas, and life cycle perspective. J. Cleaner Prod. 15, 607-619.

Wooley, R., Ruth, M., Sheehan, J., Ibsen, K., Majdeski, H., Galvez, A., 1999. Lignocellulosic Biomass to Ethanol Process Design and Economics Utilizing Co-current Dilute Acid Prehydrolysis and Enzymatic Hydrolysis: Current and Futuristic Scenarios. National Renewable Energy Laboratory (NREL), NREL Report TP580-26157. 